\title{
Heterogeneous patterns of tissue injury in NARP syndrome
}

\author{
Jeffrey M. Gelfand · Jacque L. Duncan • Caroline A. Racine • Leslie A. Gillum • \\ Cynthia T. Chin - Yuhua Zhang $\cdot$ Qing Zhang $\cdot$ Lee-Jun C. Wong $\cdot$ \\ Austin Roorda $\cdot$ Ari J. Green
}

Received: 3 September 2010/Accepted: 23 September 2010/Published online: 16 October 2010

(C) The Author(s) 2010. This article is published with open access at Springerlink.com

\begin{abstract}
Point mutations at m.8993T $>$ C and $\mathrm{m} .8993 \mathrm{~T}>\mathrm{G}$ of the mtDNA ATPase 6 gene cause the neurogenic weakness, ataxia and retinitis pigmentosa (NARP) syndrome, a mitochondrial disorder characterized by retinal, central and peripheral neurodegeneration. We performed detailed neurological, neuropsychological and ophthalmological phenotyping of a mother and four daughters with NARP syndrome from the mtDNA m.8993T $>$ C ATPase 6 mutation, including 3-T brain MRI, spectral domain optical
\end{abstract}

Electronic supplementary material The online version of this article (doi:10.1007/s00415-010-5775-1) contains supplementary material, which is available to authorized users.

J. M. Gelfand · C. A. Racine · L. A. Gillum · A. J. Green ( $₫)$

Department of Neurology, University of California,

San Francisco, CA 94143-0114, USA

e-mail: AGreen@ucsf.edu

\section{J. L. Duncan}

Department of Ophthalmology, University of California,

San Francisco, CA, USA

\section{T. Chin}

Department of Radiology, University of California,

San Francisco, CA, USA

Y. Zhang · A. Roorda

School of Optometry, University of California,

Berkeley, CA, USA

Q. Zhang

Department of Medical and Molecular Genetics,

School of Medicine,

Indiana University, Indianapolis, IN, USA

L.-J. C. Wong

Department of Molecular and Human Genetics,

Baylor College of Medicine, Houston, TX, USA coherence tomography (SD-OCT), adaptive optics scanning laser ophthalmoscopy (AOSLO), electromyography and nerve conduction studies (EMG-NCS) and formal neuropsychological testing. The degree of mutant heteroplasmy for the m.8993T $>C$ mutation was evaluated by real-time allele refractory mutation system quantitative PCR of mtDNA from hair bulbs (ectoderm) and blood leukocytes (mesoderm). There were marked phenotypic differences between family members, even between individuals with the greatest degrees of ectodermal and mesodermal heteroplasmy. 3-T MRI revealed cerebellar atrophy and cystic and cavitary $\mathrm{T} 2$ hyperintensities in the basal ganglia. SD-OCT demonstrated similarly heterogeneous areas of neuronal and axonal loss in inner and outer retinal layers. AOSLO showed increased cone spacing due to photoreceptor loss. EMG-NCS revealed varying degrees of length-dependent sensorimotor axonal polyneuropathy. On formal neuropsychological testing, there were varying deficits in processing speed, visual-spatial functioning and verbal fluency and high rates of severe depression. Many of these cognitive deficits likely localize to cerebellar and/or basal ganglia dysfunction. High-resolution retinal and brain imaging in NARP syndrome revealed analogous patterns of tissue injury characterized by heterogeneous areas of neuronal loss.

Keywords Mitochondrial disorders . Neuroophthalmology $\cdot$ Neuropsychology $\cdot$ Cerebellar disease $\cdot$ Neuropathy

\section{Introduction}

All nucleated cells in the human body contain mitochondria, the organelles responsible for intracellular energy production [1]. Each mitochondrion carries multiple copies 
of maternally inherited, circular, double-stranded mitochondrial DNA (mtDNA), which encodes for 2 rRNA, 22 tRNA, and 13 protein subunits essential for oxidative phosphorylation. Autosomal genes encode for all other mitochondrial proteins [1]. Mitochondrial DNA mutations are an important cause of neurodegeneration [2-4], and autosomally encoded mitochondrial proteins have also been implicated in a wide range of neurodegenerative conditions [5].

Point mutations at position 8993 of the mtDNA ATPase 6 gene cause neurogenic weakness, ataxia and retinitis pigmentosa (NARP) syndrome, a neurodegenerative disorder of the retina and central and peripheral nervous systems. The syndrome is named for its clinical manifestations: sensorimotor axonal polyneuropathy, ataxia, retinitis pigmentosa (RP), sensorineural hearing loss, seizures and cognitive impairment [6-10]. The same ATPase 6 point mutations that cause NARP syndrome also cause maternally inherited Leigh syndrome (MILS), a subacute necrotizing encephalomyelopathy that is a final common phenotype for a number of mutations associated with impaired energy production [11]. Since many patients with ATPase 6 mtDNA point mutations exhibit phenotypes that overlap with NARP and MILS, these previously discrete syndromes are probably best understood as part of a shared phenotypic spectrum [9].

Phenotypic variability is a cardinal feature of NARP and MILS [6, 9, 12, 13]. Mitochondrial genetic heteroplasmy, the ratio of mutant to wild-type mtDNA, helps to explain some of this variability, as greater degrees of mutant heteroplasmy tend to lead to more severe clinical deficits [1, 3]. In NARP/MILS, the risk of developing severe functional disability increases greatly past a threshold of $>60-70 \%$ mutant blood heteroplasmy for the m.8993T $>\mathrm{G}$ ATPase 6 mutation and >80-90\% blood heteroplasmy for the m.8993T $>$ C mutation [12, 14]. Environmental, autosomal and tissue-specific factors may also modulate disease expression $[15,16]$.

To better characterize the range of disease expression in NARP syndrome from the m.8993T $>$ C mutation, we performed detailed phenotyping of retinal, central and peripheral disease expression in five family members with NARP syndrome from the m.8993T $>C$ mutation.

\section{Methods}

\section{Subjects}

We evaluated a mother (M1) and four daughters (D1-D4) with the m.8993T $>$ C mtDNA ATPase 6 point mutation. The family was of Spanish and Colombian descent. M1 had one brother with coordination problems, four unaffected siblings, and a maternal aunt who had lost all four children in infancy from unknown causes. The father of D1-D4 suffered from bipolar disease.

All participants provided written informed consent. The Institutional Review Boards of UCSF and UC Berkeley approved the study protocol, and the study was performed in accordance with the Declaration of Helsinki.

Neurological evaluation

A study neurologist (A.G.) performed a comprehensive neurological examination of all five subjects. An electrophysiologist (L.G.) performed electromyography and nerve conduction studies (EMG-NCS) in three subjects.

Neuropsychological evaluations

All subjects underwent a brief interview regarding their cognitive function and approximately $2 \mathrm{~h}$ of formal neuropsychological testing using measures of global cognition, intellectual ability, verbal memory, visual-constructional skills and recall, working memory, processing speed, executive function, verbal fluency, language, reading, depression and anxiety (Electronic supplementary material). All results were converted to standard scores based on age-appropriate normative data; education-corrected normative data were also utilized when available.

\section{3-T MRI evaluation}

Four subjects had a research-quality brain MRI scan (Tim Trio 3-T MR scanner with a 12-channel head coil; Siemens Medical, Germany) which included T1 MPRAGE, T2 TSE, FLAIR, diffusion, ADC and proton-density sequences; the fifth subject (D3) had a clinical MRI scan at age 18 years, which was also analyzed. A study neuroradiologist interpreted the images.

Ophthalmological evaluation

All subjects underwent a comprehensive ophthalmological evaluation, including slit lamp and dilated fundus examination, best-corrected visual acuity using a standard eye chart, visual field testing, color vision testing, high-resolution spectral domain optical coherence tomography (SDOCT, Spectralis ${ }^{\circledR}$ HRA + OCT system, Spectralis ${ }^{\circledR} 3.1$ software; Heidelberg Engineering, Vista, CA) and full-field electroretinography (ERG), as reported previously [17]. Those with stable fixation also underwent multifocal ERG (mfERG, VERIS 5.1.10X; Electro-Diagnostic Imaging, Redwood City, CA) using a Burian-Allen contact lens electrode, following ISCEV standards as previously described [17]. Three subjects underwent adaptive optics scanning laser ophthalmoscopy (AOSLO) imaging with 
cone spacing analysis using customized equipment and software at the UC Berkeley School of Optometry [17-21].

Mitochondrial DNA point mutation analysis

Twenty different hair bulb samples (ectoderm) from three different scalp locations were obtained from each subject, and the DNA was extracted and amplified using PCR. Total DNA from blood leukocytes was also extracted from whole-blood samples (mesoderm) and amplified with PCR using specific primer pairs. The presence of the heteroplasmic m.8993T $>$ C mutation was detected by allele-specific oligonucleotide dot blot analyses followed by quantification of the degree of heteroplasmy using real-time allele refractory mutation system (ARMS) quantitative PCR $[22,23]$. The primers used for real-time ARMS-qPCR were: forward wild-type (ARMS T8993-1m) 5'-TACTCATT CAACCAATAGCCaT-3', mutant type (ARMST8993C$1 \mathrm{~m}) 5^{\prime}$-TACTCATTCAACCAATAGCCaC-3', and shared reverse primer (mtR9046) 5'-TTAGGTGCATGAGTAG GTGGC-3'. The analyses of the testing samples were repeated four times using the pooled DNA samples and quality control samples with known heteroplasmy content. The reaction was run in duplicate for each analysis. The intrarun and interrun differences were less than 20 and $30 \%$, respectively. The final heteroplasmy rate was calculated by averaging the values obtained in duplicate runs [17].

\section{Results}

Table 1 summarizes the range of neurological, neuropsychological and ophthalmological disease expression in this family with NARP syndrome.

\section{Genotype-phenotype correlation}

The four family members with mutant heteroplasmy greater than $78 \%$ in the blood and $87 \%$ in the hair bulbs suffered from sensorimotor axonal polyneuropathy and $\mathrm{RP}$, and the three daughters with the greatest degree of mutant heteroplasmy ( $>78 \%$ in the blood and $99 \%$ in the hair bulbs) also had ataxia and cerebellar degeneration. Heteroplasmy rates were greater in pooled hair bulb samples than in blood. There was marked variability in the types of tissues affected within individuals. For example, one daughter with $99.9 \%$ hair bulb and $78 \%$ leukocyte heteroplasmy (D1) suffered from moderate ataxia and severe RP, while her sister with 99\% hair bulb and 95\% leukocyte heteroplasmy (D3) had severe ataxia but only moderate RP.

The age at time of first symptom ranged from ataxia at 13 months in subject D3 to visual impairment at 10, 12 and
34 years in D4, D1 and M1, respectively, which also correlated inversely with heteroplasmy.

Peripheral neurodegeneration

Four of the five subjects (all except D2) had evidence of peripheral neuropathy on clinical examination, most commonly characterized by large-fiber sensory deficits and absent S1 deep-tendon reflexes. Three subjects underwent EMG-NCS, which revealed decreased or absent sural sensory nerve action potential amplitudes, and long-duration, high-amplitude motor unit action potentials and reduced recruitment in the abductor hallucis longus. These findings are consistent with a length-dependent sensorimotor axonal polyneuropathy.

Cerebellar degeneration

The three subjects (D1, D3 and D4) with the greatest degrees of blood and hair bulb heteroplasmy suffered from ataxia, with varying combinations of dysmetria, dysdiadochokinesia, tremor, dysarthria, imbalance, saccadic overshoot, end-gaze jerk nystagmus, and impaired tandem gait. Truncal stability was preserved in all subjects. While all patients experienced chronic, progressive worsening of cerebellar symptoms over time, two of the three subjects (D3 and D4) also experienced additional, punctuated episodes of profound worsening of ataxia, which were associated temporally with adolescence, oral contraceptive pills and pregnancy.

\section{3-T MRI: cerebellar and basal ganglia abnormalities}

MRI of the brain was abnormal in all five family members, but the severest abnormalities occurred in those with the greatest degrees of mutant heteroplasmy (Table 1; Fig. 1a). The lesions involved the bilateral putamen in all subjects and the anterior commissure, frontal gyrus recti and caudate heads in the most affected subjects. All three daughters with ataxia (D1, D3 and D4) showed cerebellar atrophy on MRI scans (Fig. 1b), and the degree of atrophy correlated with the severity of the clinical deficit. D3 had diffuse cortical, corpus callosal, pontine and cervical cord atrophy, and M1, the oldest subject, also had mild global brain atrophy.

\section{Neuropsychological profiles}

The most consistent cognitive deficits in this family were impairments in processing speed, visual-spatial copy and recall and verbal fluency (see Table 1; Electronic Supplementary Material). D1, who had severe visual deficits from RP, had mild verbal fluency impairment. M1 and D4 had 
Table 1 Phenotypic characterization of a family with NARP syndrome from the m.8993T $>$ C ATPase 6 mutation

\begin{tabular}{|c|c|c|c|c|c|}
\hline & Mother (Ml) & Daughter 1 (Dl) & Daughter 2 (D2) & Daughter 3 (D3) & Daughter 4 (D4) \\
\hline Age (years) & 48 & 28 & 26 & 22 & 16 \\
\hline $\begin{array}{l}\text { Hair-bulb } \\
\text { heteroplasmy }(\%)\end{array}$ & 87 & 99 & 54 & 99 & 99 \\
\hline $\begin{array}{l}\text { Leukocyte } \\
\text { heteroplasmy (\%) }\end{array}$ & 78 & 78 & 42 & 95 & 92 \\
\hline Clinical symptoms & $\begin{array}{l}\text { RP, mild numbness, } \\
\text { weakness, } \\
\text { depression }\end{array}$ & $\begin{array}{l}\text { Severe RP, moderate } \\
\text { ataxia, neuropathy, } \\
\text { weakness, depression }\end{array}$ & $\begin{array}{l}\text { Remote history } \\
\text { of depression } \\
\text { with suicidal } \\
\text { ideation }\end{array}$ & $\begin{array}{l}\text { Severe ataxia, moderate } \\
\text { RP, remote depression }\end{array}$ & $\begin{array}{l}\text { Severe RP, episodic mild } \\
\text { ataxia, mild depression }\end{array}$ \\
\hline $\begin{array}{l}\text { Neurological } \\
\text { examination }\end{array}$ & $\begin{array}{l}\text { Mild asymmetric } \\
\text { weakness, absent } \\
\text { triceps and S1 } \\
\text { reflexes, decreased } \\
\text { pain and vibration } \\
\text { sense in the feet }\end{array}$ & $\begin{array}{l}\text { Lingual dysarthria, } \\
\text { moderate proximal } \\
\text { weakness, mildly } \\
\text { decreased vibration } \\
\text { sense in the feet, } \\
\text { moderate dysmetria, } \\
\text { impaired tandem } \\
\text { (straight line) gait }\end{array}$ & Normal & $\begin{array}{l}\text { Nystagmus, saccadic } \\
\text { breakdown, dysarthria, } \\
\text { moderate weakness, } \\
\text { spasticity, absent S1 } \\
\text { reflex, dysmetria, } \\
\text { tremor, impaired } \\
\text { tandem (straight line) } \\
\text { gait, decreased pain } \\
\text { and vibration sense in } \\
\text { the feet }\end{array}$ & $\begin{array}{l}\text { Overshot saccades, mild } \\
\text { proximal weakness, } \\
\text { moderate dysmetria } \\
\text { and } \\
\text { dysdiadochokinesia, } \\
\text { decreased S1 reflexes, } \\
\text { decreased pain and } \\
\text { vibration sense in the } \\
\text { feet }\end{array}$ \\
\hline EMG-NCS & $\begin{array}{l}\text { Sensorimotor axonal } \\
\text { polyneuropathy }\end{array}$ & Not done & Not done & $\begin{array}{l}\text { Sensorimotor axonal } \\
\text { polyneuropathy }\end{array}$ & $\begin{array}{l}\text { Sensorimotor axonal } \\
\text { polyneuropathy }\end{array}$ \\
\hline MRI & $\begin{array}{l}\text { Cystic/cavitary } \mathrm{T} 2 \\
\text { hyperintensities in } \\
\text { the bilateral } \\
\text { putamina and globus } \\
\text { pallidi, mild } \\
\text { cerebellar atrophy, } \\
\text { mild global volume } \\
\text { loss }\end{array}$ & $\begin{array}{l}\text { Cystic/cavitary T2 } \\
\text { hyperintensities in } \\
\text { bilateral putamina, } \\
\text { anterior commissure, } \\
\text { frontal gyrus recti, } \\
\text { cerebellar atrophy }\end{array}$ & $\begin{array}{l}\text { Mild T2 cystic/ } \\
\text { cavitary } \\
\text { changes in } \\
\text { basal ganglia }\end{array}$ & $\begin{array}{l}\text { (Performed at age } \\
18 \text { years) Diffuse } \\
\text { atrophy of cortex, } \\
\text { cerebellum and } \\
\text { cervical cord, T2 } \\
\text { cystic/cavitary basal } \\
\text { ganglia } \\
\text { hyperintensities }\end{array}$ & $\begin{array}{l}\text { Cystic/cavitary } \mathrm{T} 2 \\
\text { hyperintensities in the } \\
\text { anterior putamina and } \\
\text { caudate heads, mild } \\
\text { cerebellar atrophy }\end{array}$ \\
\hline $\begin{array}{l}\text { Neuropsychological } \\
\text { testing }\end{array}$ & $\begin{array}{l}\text { MMSE 29/30; } \\
\text { selective } \\
\text { impairments in } \\
\text { information } \\
\text { processing speed, } \\
\text { set-shifting, and } \\
\text { visual-spatial skills }\end{array}$ & $\begin{array}{l}\text { MMSE } 27 / 27 \text { (excluding } \\
\text { visual tasks); selective } \\
\text { mild deficits in verbal } \\
\text { fluency }\end{array}$ & $\begin{array}{l}\text { MMSE 29/30; } \\
\text { grossly normal } \\
\text { with the } \\
\text { exception of } \\
\text { slightly } \\
\text { variable } \\
\text { information } \\
\text { processing } \\
\text { speed }\end{array}$ & $\begin{array}{l}\text { MMSE 27/30; relative } \\
\text { sparing of verbal } \\
\text { abilities with } \\
\text { impairments in motor } \\
\text { speed, information } \\
\text { processing speed, } \\
\text { visual-spatial skills and } \\
\text { memory }\end{array}$ & $\begin{array}{l}\text { MMSE 30/30; selective } \\
\text { impairments in motor } \\
\text { speed, information } \\
\text { processing speed, } \\
\text { verbal fluency, and } \\
\text { visual recall (despite } \\
\text { adequate copy } \\
\text { performance) }\end{array}$ \\
\hline Mood & $\begin{array}{l}\text { Moderate depression } \\
\text { with suicidal } \\
\text { ideation }\end{array}$ & $\begin{array}{l}\text { Severe depression with } \\
\text { moderate anxiety, } \\
\text { despite antidepressant } \\
\text { therapy; remote history } \\
\text { of suicide attempt }\end{array}$ & $\begin{array}{l}\text { Remote history } \\
\text { of depression } \\
\text { with suicidal } \\
\text { ideation }\end{array}$ & $\begin{array}{l}\text { Remote history of } \\
\text { depression }\end{array}$ & $\begin{array}{l}\text { Mild depression with } \\
\text { severe anxiety }\end{array}$ \\
\hline $\begin{array}{l}\text { Best-corrected } \\
\text { visual acuity }\end{array}$ & $20 / 50$ & $5 / 125$ & $20 / 16$ & $20 / 25$ & $20 / 50$ \\
\hline $\begin{array}{l}\text { High-resolution } \\
\text { optical coherence } \\
\text { tomography }\end{array}$ & $\begin{array}{l}\text { Moderate-severe } \\
\text { photoreceptor layer } \\
\text { thinning, with mild } \\
\text { involvement of } \\
\text { retinal nerve fiber } \\
\text { layer }\end{array}$ & $\begin{array}{l}\text { Severe foveal thinning, } \\
\text { including } \\
\text { photoreceptor layer, } \\
\text { retinal pigment } \\
\text { epithelial layer and } \\
\text { retinal nerve fiber } \\
\text { layer/ganglion cell } \\
\text { layer }\end{array}$ & Not done & $\begin{array}{l}\text { Patchy ring of } \\
\text { photoreceptor/retinal } \\
\text { nerve fiber layer } \\
\text { thinning }\end{array}$ & $\begin{array}{l}\text { Progressive thinning of } \\
\text { the temporal } \\
\text { photoreceptor/retinal } \\
\text { nerve fiber layer }\end{array}$ \\
\hline
\end{tabular}

$R P$ retinitis pigmentosa, $M M S E$ mini-mental state examination 
Fig. 1 High-resolution retinal and brain imaging in NARP syndrome demonstrates analogous patterns of tissue injury. This 28-year-old woman (D1) with NARP syndrome from the mtDNA ATPase 6 m.8993T $>$ C mutation with $78 \%$ blood leukocyte and $99 \%$ hair-bulb heteroplasmy had severe RP and moderate ataxia. a, b 3-T MRI demonstrates cystic and cavitary $\mathrm{T} 2$ hyperintensities in the bilateral putamina (a), likely reflecting neuronal necrosis, and also moderate cerebellar atrophy with T1 imaging (b). c Highresolution OCT image of the macula demonstrates severe retinal thinning, primarily due to degeneration of the photoreceptor and the retinal pigment epithelial cell layers, but also associated thinning of the ganglion cell $(G C L)$ and retinal nerve fiber layer $(R N F L)$. d Macular OCT image from an age-similar normal female shown for comparison
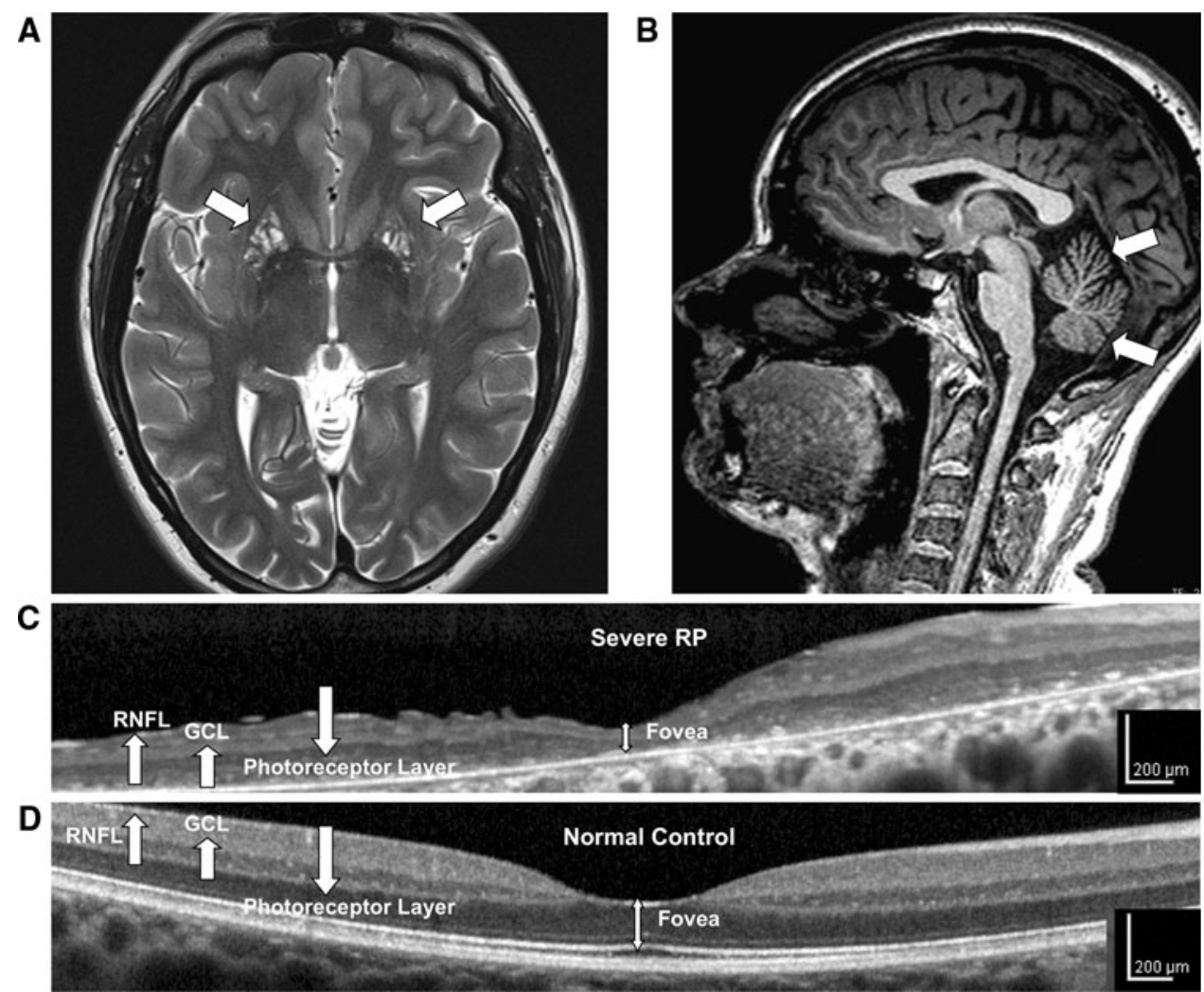

significant deficits in information processing speed and visual-spatial functioning (see Fig. 2). D3, who suffered the severest cerebellar injury, had deficits in processing speed, motor speed, memory and visual-spatial functioning. D2, who was unaffected clinically, tested normally in all cognitive domains. The mini-mental state examination was an insensitive screen for cognitive deficits in this family, as it was near normal in all subjects (range 27/ 30-30/30).

Affective symptoms were prominent in this family, with all five family members having a significant history of depression, many with suicidal ideation. D3 subsequently developed severe psychosis and depression requiring psychiatric hospitalization.

\section{Retinal neurodegeneration}

Four of the five subjects demonstrated varying degrees of RP. The best-corrected visual acuity (BCVA) ranged from 20/25 in mild RP (D3) to 5/125 in severe RP (D1). Retinal vascular attenuation was present in all affected subjects, while bone-spicule pigmentary changes and retinal pigment epithelium atrophy were observed in those with severe RP. Full-field ERG demonstrated varying degrees of decreased rod-mediated, cone-mediated and mixed rodand cone-mediated amplitudes, while multifocal ERG revealed that the macular photoreceptors had the greatest functional impairment, with relative sparing of more peripheral photoreceptors. SD-OCT (Figs. 1 and 3) revealed macular thinning, especially of the photoreceptor (RPE) layer, but also thinning of the retinal nerve fiber and ganglion cell layers in proportion to the severity of RP. AOSLO in the four subjects capable of stable fixation revealed increased cone spacing with variable degrees of patchy cone loss and abnormally enlarged foveal cones (Fig. 3d). There was normal cone spacing on AOSLO in subject D2, who had no visual symptoms (Fig. 3e) [17].

\section{Discussion}

We describe the range of retinal, peripheral and central nervous system disease expression in a single family with NARP syndrome from the ATPase $6 \mathrm{~m} .8993 \mathrm{~T}>\mathrm{C} \mathrm{mtDNA}$ point mutation. Even amongst family members with the greatest degrees of ectodermal and mesodermal heteroplasmy, there was great variability in tissue types affected and severity of injury within those tissues.

All subjects in our series had greater degrees of hairbulb heteroplasmy than blood leukocyte heteroplasmy, but the overall trends were similar. Family members with the greatest degrees of hair-bulb and leukocyte heteroplasmy suffered the severest neurological and ophthalmological deficits, but neither hair-bulb nor leukocyte heteroplasmy 


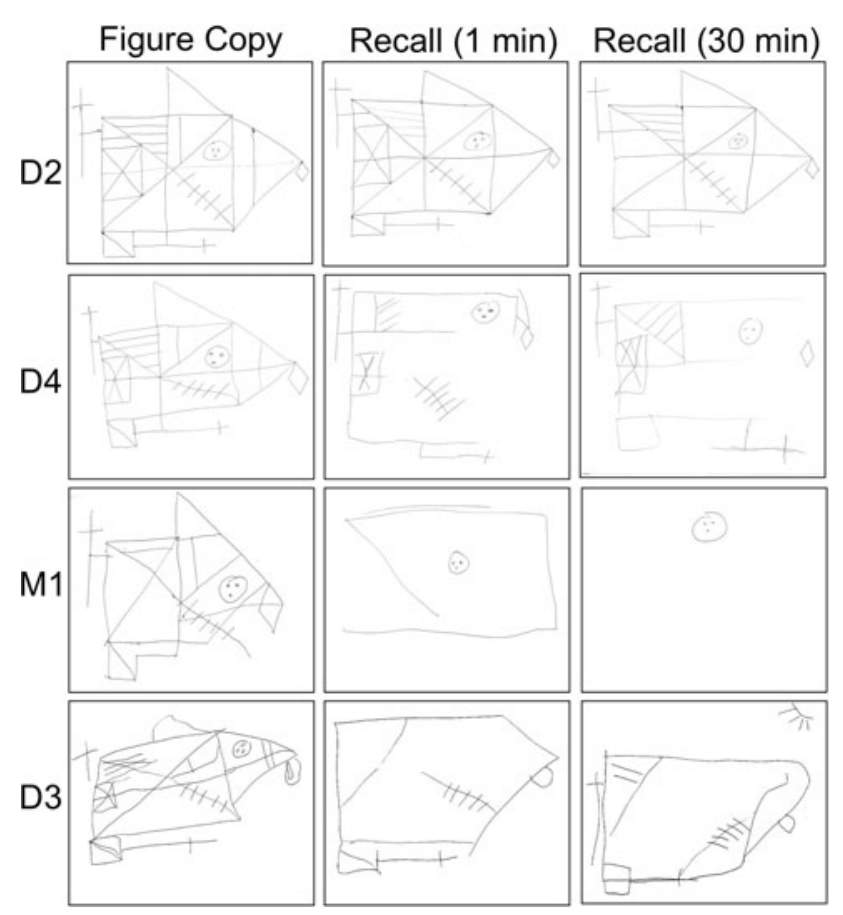

Fig. 2 Visual-spatial deficits in NARP syndrome reflect impaired cognitive functioning, not just poor vision. Subject D4, despite moderate RP causing impaired vision, had normal visual-spatial constructional skills using the Rey-Osterrieth complex figure, but exhibited deficits in visual-spatial recall. On the other hand, M1 and D3, who both also suffered from moderate to severe RP, had difficulty with both visual copy and visual recall (D1 could not perform either of the tasks due to severe visual loss). D2, who was clinically unaffected, performed normally on both tasks

uniformly predicted which tissues would be affected in a given individual or the severity of deficits within a given tissue (Table 1).

There were analogous patterns of tissue injury on highresolution retinal and brain imaging characterized by heterogeneous, patchy areas of neuronal loss (Figs. 1c, d, and 3d, e). With 3-T MRI, we were able to appreciate that the basal ganglia hyperintensities typical of NARP-MILS spectrum disease $[12,13,24]$ are not homogeneous, but rather consist of multiple, small cystic and cavitary lesions. These basal ganglia hyperintensities likely reflect discrete foci of tissue loss from mitochondria-related energy failure [13]. Since basal ganglia necrosis is also a defining feature of MILS, the prominence of this finding in our study reinforces the concept that NARP and MILS reflect overlapping phenotypes of ATPase 6 dysfunction $[3,6,9,12$, 13].

We observed similar patterns of heterogeneous, focal and destructive injury to neuronal layers of the inner and outer retina. On SD-OCT, the most prominent abnormality was thinning of the photoreceptor (RPE) layer with scattered areas of severe neuronal loss causing a disruption to normal retinal architecture. There was also associated thinning of the retinal nerve fiber and ganglion cell layers in proportion to the degree of RPE injury. Since RNFL thinning is common in other types of retinitis pigmentosa [25] and the severest injury was to the outer retina, we suspect that the primary retinal injury in NARP syndrome is to energy-dependent photoreceptors followed by secondary transsynaptic degeneration of neighboring retinal layers [26]. The abnormalities observed on SD-OCT and AOSLO are also consistent with findings on retinal pathology from a child who died from MILS from the m.8993T $>$ G mutation [27], and illustrate how high-resolution retinal imaging can detect neurodegenerative injury in a mitochondrial disorder.

Our study demonstrates that cognitive impairment in NARP-MILS is characterized by selective dysfunction of specific functional domains, especially in information processing speed, visual-spatial copy and memory and verbal fluency. The visual-spatial deficits were independent of the degree of primary visual loss from RP (see Fig. 2). Visualspatial and executive function impairment are characteristic of other mitochondrial cytopathies, such as chronic progressive external ophthalmoplegia and Kearns-Sayre syndrome, and the localization of these deficits has been attributed to the prefrontal, parietal and occipital cortex [28, 29]. However, cerebellar dysfunction also causes deficits in executive functioning, verbal fluency, memory and visualspatial processing [30], and striatal networks also modulate many cognitive processes, including language, and executive and visual-spatial functioning [31, 32]. Given the extensive cerebellar and basal ganglia injury seen in NARP syndrome with relative sparing of cortical structures, we propose that some of the cognitive deficits characteristic of NARP-MILS spectrum disease may be due to cerebellar and basal ganglia dysfunction. Our results also suggest that the mini-mental state examination is not an adequate screening test for cognitive dysfunction in NARP syndrome, and that clinicians should pursue more sensitive evaluations focused on information processing speed, verbal fluency and visual-spatial function.

Two main factors argue against depression confounding the neuropsychological testing results [33]. First, all subjects showed similar patterns of deficits, despite variability in affective symptoms. Second, verbal and working memory tend to be impaired when depression causes cognitive deficits [34], but these domains were not significantly affected in this family, even in those subjects with the severest depression. Depression has not traditionally been recognized as part of the NARP-MILS phenotypic spectrum, but the prominence of affective symptoms in this family raises the question as to whether mitochondrial dysfunction may be involved in its pathogenesis [35]. Depression is common in mitochondrial cytopathies [36, 


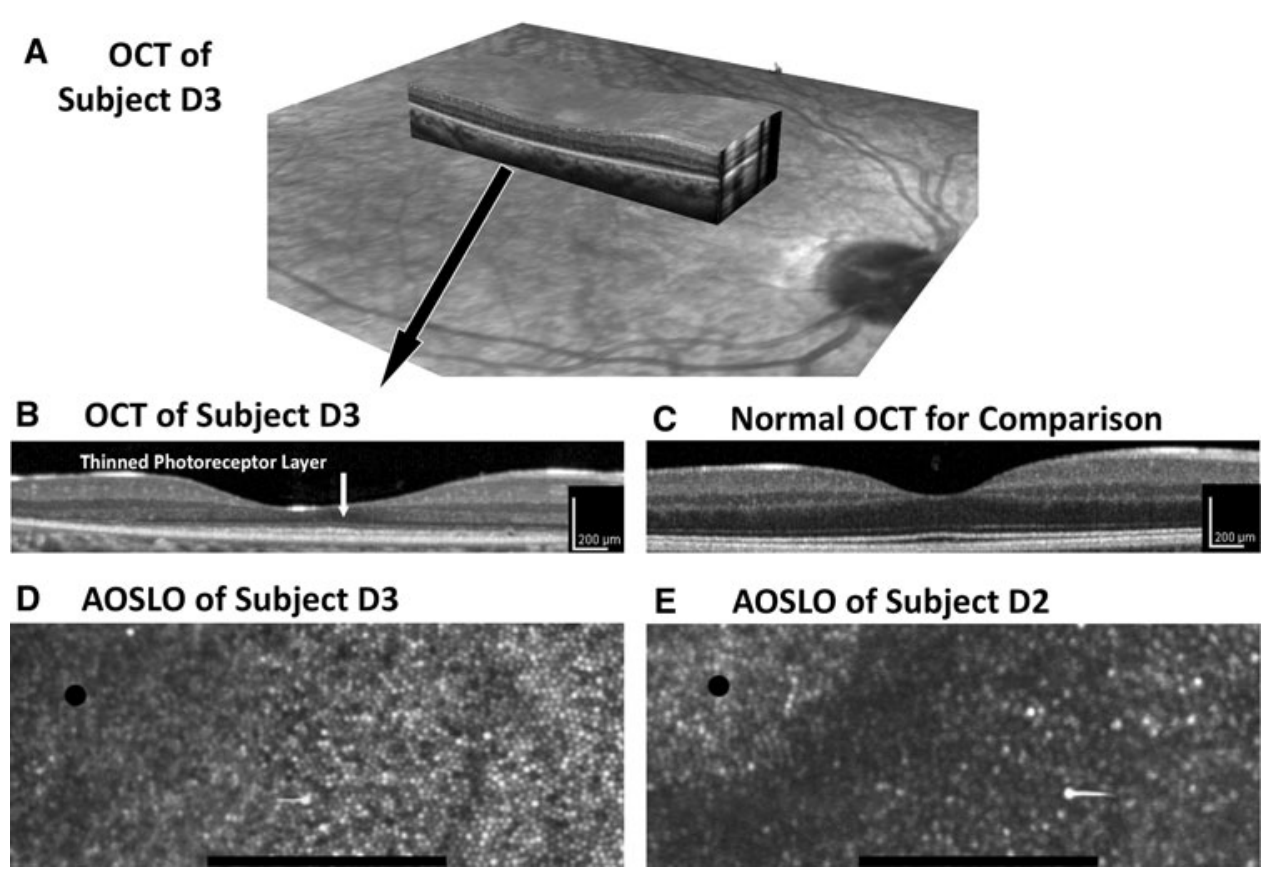

Fig. 3 Patterns of retinal injury in NARP syndrome. Infrared fundus image (a) and OCT of the macula (a, b) in a 22-year-old woman with NARP syndrome (D3) demonstrate moderate thinning of the photoreceptor layer, as well as associated thinning of the retinal pigment epithelial, retinal nerve fiber and ganglion cell layers. $\mathbf{c}$ Macular OCT image of an age-similar normal female shown for comparison. d AOSLO image of the fovea (black dot) reveals a contiguous pattern

37], and is also prominent in other neurodegenerative disorders that affect striatal networks, including Huntington's and Parkinson's diseases [38, 39]. In our analysis, however, we were not able to account for other factors that might have influenced depression risk in this family, including the history of bipolar disease in the father of D1D4 or shared environmental exposures. More research is needed to explore this possible association between depression and mitochondrial disease further.

There are several limitations to this study. We characterized disease expression in a single family, which risks overemphasizing shared autosomal or environmental factors that can influence mitochondrial disease expression or confound phenotypes. It is also difficult in this kind of analysis to account for the effects of age on mitochondrial disease progression. We also did not measure heteroplasmy using the urinary epithelium, which has been recently reported to predict neurological involvement in MELAS [40]. Nevertheless, we believe that this study adds to our understanding of the range of phenotypic expression seen in this prototypical mitochondrial neurodegenerative disorder.

In summary, this study characterized patterns of disease expression in NARP syndrome from the m.8993T $>C$ ATPase 6 mtDNA mutation and illustrated how neurodegeneration in the retina, brain and peripheral nervous system can share common mechanisms. of decreased cone density in the sampled area due to photoreceptor loss (which makes it easier to resolve the individual photoreceptors in the image). e In contrast, AOSLO image of the fovea in her sister (D2), who had normal vision, shows a normal pattern of high-density, closely packed cones (black scale bars angular distance $0.5^{\circ}$, approximately $150 \mu \mathrm{m}$ )

Acknowledgments We acknowledge the support of the following organizations: American Academy of Neurology Foundation/National MS Society Early Clinician Scientist Award (A.J.G.); NIH-NCRR KL2RR024130 (A.J.G., L.A.G.); Career Development Award, Physician Scientist Award and Unrestricted Grant from the Research to Prevent Blindness (J.L.D.); Career Development Award and Clinical Center Grant from the Foundation Fighting Blindness (J.L.D., A.R.); NIH-NEI grants EY002162 (J.L.D.) and EY014375 (A.R.); That Man May See, Inc. (J.L.D.); The Bernard A. Newcomb Macular Degeneration Fund (J.L.D.); Hope for Vision (J.L.D.); the Karl Kirchgessner Foundation (J.L.D.); and NSF Science and Technology Center for Adaptive Optics, managed by the University of California at Santa Cruz under cooperative agreement \#AST-9876783 (A.R.).

Conflict of interest Dr. Roorda reports that he holds a patent for the adaptive optics scanning laser ophthalmoscope used in this study. The other authors have no disclosures to report.

Open Access This article is distributed under the terms of the Creative Commons Attribution Noncommercial License which permits any noncommercial use, distribution, and reproduction in any medium, provided the original author(s) and source are credited.

\section{References}

1. Taylor RW, Turnbull DM (2005) Mitochondrial DNA mutations in human disease. Nat Rev Genet 6(5):389-402

2. Schaefer AM, McFarland R, Blakely EL, He L, Whittaker RG, Taylor RW, Chinnery PF, Turnbull DM (2008) Prevalence of mitochondrial DNA disease in adults. Ann Neurol 63(1):35-39 
3. Thorburn DR, Dahl HH (2001) Mitochondrial disorders: genetics, counseling, prenatal diagnosis and reproductive options. Am J Med Genet 106(1):102-114

4. Abramov AY, Smulders-Srinivasan TK, Kirby DM, Acin-Perez R, Enriquez JA, Lightowlers RN, Duchen MR, Turnbull DM (2010) Mechanism of neurodegeneration of neurons with mitochondrial DNA mutations. Brain 133(Pt 3):797-807. doi: 10.1093/brain/awq015

5. Lin MT, Beal MF (2006) Mitochondrial dysfunction and oxidative stress in neurodegenerative diseases. Nature 443(7113): 787-795

6. Santorelli FM, Tanji K, Shanske S, DiMauro S (1997) Heterogeneous clinical presentation of the mtDNA NARP/t8993G mutation. Neurology 49(1):270-273

7. Holt IJ, Harding AE, Petty RK, Morgan-Hughes JA (1990) A new mitochondrial disease associated with mitochondrial DNA heteroplasmy. Am J Hum Genet 46(3):428-433

8. Morava E, Rodenburg RJ, Hol F, de Vries M, Janssen A, van den Heuvel L, Nijtmans L, Smeitink J (2006) Clinical and biochemical characteristics in patients with a high mutant load of the mitochondrial t8993G/C mutations. Am J Med Genet A 140(8): 863-868

9. Sciacco M, Prelle A, D’Adda E, Lamperti C, Bordoni A, Rango M, Crimi M, Comi GP, Bresolin N, Moggio M (2003) Familial mtDNA T8993C transition causing both the NARP and the MILS phenotype in the same generation. A morphological, genetic and spectroscopic study. J Neurol 250(12):1498-1500

10. Keranen T, Kuusisto H (2006) NARP syndrome and adult-onset generalised seizures. Epileptic Disord 8(3):200-203

11. Santorelli FM, Shanske S, Macaya A, DeVivo DC, DiMauro S (1993) The mutation at nt 8993 of mitochondrial DNA is a common cause of Leigh's syndrome. Ann Neurol 34(6):827-834

12. Uziel G, Moroni I, Lamantea E, Fratta GM, Ciceri E, Carrara F, Zeviani M (1997) Mitochondrial disease associated with the T8993G mutation of the mitochondrial ATPase 6 gene: a clinical, biochemical, and molecular study in six families. J Neurol Neurosurg Psychiatry 63(1):16-22

13. Rojo A, Campos Y, Sanchez JM, Bonaventura I, Aguilar M, Garcia A, Gonzalez L, Rey MJ, Arenas J, Olive M, Ferrer I (2006) NARP-MILS syndrome caused by $8993 \mathrm{~T}>\mathrm{G}$ mitochondrial DNA mutation: a clinical, genetic and neuropathological study. Acta Neuropathol 111(6):610-616

14. White SL, Collins VR, Wolfe R, Cleary MA, Shanske S, DiMauro S, Dahl HH, Thorburn DR (1999) Genetic counseling, prenatal diagnosis for the mitochondrial DNA mutations at nucleotide 8993. Am J Hum Genet 65(2):474-482

15. Jenuth JP, Peterson AC, Shoubridge EA (1997) Tissue-specific selection for different mtDNA genotypes in heteroplasmic mice. Nat Genet 16(1):93-95

16. Kirkman MA, Yu-Wai-Man P, Korsten A, Leonhardt M, Dimitriadis K, De Coo IF, Klopstock T, Chinnery PF (2009) Geneenvironment interactions in Leber hereditary optic neuropathy. Brain 132(Pt 9):2317-2326. doi:10.1093/brain/awp158

17. Yoon MK, Roorda A, Zhang Y, Nakanishi C, Wong LJ, Zhang Q, Gillum L, Green A, Duncan JL (2009) Adaptive optics scanning laser ophthalmoscopy images in a family with the mitochondrial DNA T8993C mutation. Invest Ophthalmol Vis Sci 50(4): 1838-1847. doi:10.1167/iovs.08-2029

18. Liang J, Williams DR, Miller DT (1997) Supernormal vision and high-resolution retinal imaging through adaptive optics. J Opt Soc Am A Opt Image Sci Vis 14(11):2884-2892

19. Roorda A, Romero-Borja F, Donnelly W III, Queener H, Hebert T, Campbell M (2002) Adaptive optics scanning laser ophthalmoscopy. Opt Express 10(9):405-412

20. Zhang Y, Poonja S, Roorda A (2006) MEMS-based adaptive optics scanning laser ophthalmoscopy. Opt Lett 31(9):1268-1270
21. Duncan JL, Zhang Y, Gandhi J, Nakanishi C, Othman M, Branham KE, Swaroop A, Roorda A (2007) High-resolution imaging with adaptive optics in patients with inherited retinal degeneration. Invest Ophthalmol Vis Sci 48(7):3283-3291. pii:89268

22. Wong LJ, Lam CW (1997) Alternative, noninvasive tissues for quantitative screening of mutant mitochondrial DNA. Clin Chem 43(7):1241-1243

23. Wong LJ, Bai RK (2006) Real-time quantitative polymerase chain reaction analysis of mitochondrial DNA point mutation. Methods Mol Biol 335:187-200. doi:10.1385/1-59745-0693:187

24. Suzuki Y, Wada T, Sakai T, Ishikawa Y, Minami R, Tachi N, Saitoh S (1998) Phenotypic variability in a family with a mitochondrial DNA T8993C mutation. Pediatr Neurol 19(4):283-286

25. Walia S, Fishman GA, Edward DP, Lindeman M (2007) Retinal nerve fiber layer defects in RP patients. Invest Ophthalmol Vis Sci 48(10):4748-4752

26. Vanburen JM (1963) Trans-synaptic retrograde degeneration in the visual system of primates. J Neurol Neurosurg Psychiatry 26:402-409

27. Hayashi N, Geraghty MT, Green WR (2000) Ocular histopathologic study of a patient with the $\mathrm{T}$ 8993-G point mutation in Leigh's syndrome. Ophthalmology 107(7):1397-1402

28. Bosbach S, Kornblum C, Schroder R, Wagner M (2003) Executive and visuospatial deficits in patients with chronic progressive external ophthalmoplegia and Kearns-Sayre syndrome. Brain 126(Pt 5):1231-1240

29. Finsterer J (2009) Mitochondrial disorders, cognitive impairment and dementia. J Neurol Sci 283(1-2):143-148. doi:10.1016/ j.jns.2009.02.347

30. Schmahmann JD, Sherman JC (1998) The cerebellar cognitive affective syndrome. Brain 121(Pt 4):561-579

31. De Diego-Balaguer R, Couette M, Dolbeau G, Durr A, Youssov K, Bachoud-Levi AC (2008) Striatal degeneration impairs language learning: evidence from Huntington's disease. Brain 131(Pt 11):2870-2881

32. Lawrence AD, Watkins LH, Sahakian BJ, Hodges JR, Robbins TW (2000) Visual object and visuospatial cognition in Huntington's disease: Implications for information processing in corticostriatal circuits. Brain 123(Pt 7):1349-1364

33. Castaneda AE, Tuulio-Henriksson A, Marttunen M, Suvisaari J, Lonnqvist J (2008) A review on cognitive impairments in depressive and anxiety disorders with a focus on young adults. J Affect Disord 106(1-2):1-27

34. Gualtieri CT, Johnson LG, Benedict KB (2006) Neurocognition in depression: patients on and off medication versus healthy comparison subjects. J Neuropsychiatry Clin Neurosci 18(2): 217-225

35. Kasahara T, Kubota M, Miyauchi T, Noda Y, Mouri A, Nabeshima T, Kato T (2006) Mice with neuron-specific accumulation of mitochondrial DNA mutations show mood disorder-like phenotypes. Mol Psychiatry 11 (6):577-593, 523

36. Fattal O, Link J, Quinn K, Cohen BH, Franco K (2007) Psychiatric comorbidity in 36 adults with mitochondrial cytopathies. CNS Spectr 12(6):429-438

37. Koene S, Kozicz TL, Rodenburg RJ, Verhaak CM, de Vries MC, Wortmann S, van de Heuvel L, Smeitink JA, Morava E (2008) Major depression in adolescent children consecutively diagnosed with mitochondrial disorder. J Affect Disord 114(1-3):327-332

38. Rosenblatt A, Leroi I (2000) Neuropsychiatry of Huntington's disease and other basal ganglia disorders. Psychosomatics 41(1):24-30

39. Aarsland D, Marsh L, Schrag A (2009) Neuropsychiatric symptoms in Parkinson's disease. Mov Disord 24(15):2175-2186. doi: $10.1002 /$ mds. 22589 
40. Whittaker RG, Blackwood JK, Alston CL, Blakely EL, Elson JL, McFarland R, Chinnery PF, Turnbull DM, Taylor RW (2009) Urine heteroplasmy is the best predictor of clinical outcome in the $\mathrm{m} 3243 \mathrm{~A}>\mathrm{G}$ mtDNA mutation. Neurology 72(6):568-569. doi:10.1212/01.wnl.0000342121.91336.4d 